\title{
Corporate Diversification and Corporate Social Performance in Indonesia
}

\author{
Dina Patrisia', Shabbir Dastgir ${ }^{2}$, Abror $^{3 *}$ \\ ${ }^{*}$ Corresponding author
}

\begin{abstract}
The relationship between corporate diversification and corporate social performance (CSP) is under-investigated, especially in emerging countries. This study examines the relationship between corporate diversification and CSP in Indonesia setting. Occurrence disclosure analysis has been applied to measure CSP based on 80 indicators of the Global Report Initiative (GRI). This study used multiple regressions with one-year lag dependent variables as the data analysis. The results show that the related diversification is negatively and significantly related to CSP, while, the unrelated diversification reveals a positive relationship with CSP. Besides that, unrelated diversification more correlated to CSP rather than related diversification. Furthermore, international diversification has a positive and significant relationship with CSP. Therefore, this study found that corporate diversification is a significant antecedent of CSP.
\end{abstract}

Keywords: corporate diversification, related diversification, unrelated diversification, international diversification, corporate social performance

JEL Classification: L25, M14

\begin{abstract}
Abstrak. Penelitian terdahulu yang menyelidiki Pengaruh diversifikasi usaha terhadap Kinerja sosial Perusahaan (CSP) masih terbatas, khususnya pada negara yang ekonominya sedang berkembang. Oleh sebab itu, penelitian ini menguji pengaruh diversifikasi usaha terhadap kinerja social perusahaan (CSP) di Indonesia. Pengukuran CSP pada penelitian ini menggunakan analisis pengungkapan berdasarkan 80 indikator CSP yang ditetapkan oleh Global Report Initiative (GRI). Analisis regresi berganda dengan lag satu tahun antara variable terikat dengan variable bebas digunakan untuk menganalisis data. Hasilnya memperlihatkan bahwa diversifikasi usaha yang bersifat terkait memiliki pengaruh yang negatif terhadap CSP, sementara diversifikasi yang tidak terkait justru memiliki pengaruh positif. Lebih lanjut, penelitian ini menemukan hubungan yang positif dan signifikan antara diversifikasi internasional dengan CSP. Dapat disimpulkan bahwa diversifikasi merupakan salah satu variable yang mempengaruhi CSP.
\end{abstract}

Kata Kunci: diversifikasi perusahaan, diversifikasi terkait, diversifikasi tidak terkait, diversifikasi internasional, kinerja sosial perusahaan

\section{How to Cite:}

Patrisia, D., Dastgir, S., \& Abror. (2019). Corporate Diversification and Corporate Social Performance in Indonesia. Etikonomi: Jurnal Ekonomi. Vol. 18 (2): 221 - 232. doi: http//dx.doi.org/10.15408/etk.v18i2.11816. 


\section{Introduction}

Corporate diversification has extensively studied in strategic management research (Kang, 2013; Wan et al., 2011; Zahavi \& Lavie, 2013). The prior studies have investigated both antecedent and consequence of the diversification (Kang, 2013). However, research on the consequence of diversification is still centralized on corporate financial performance (Kang, 2013; Patrisia \& Dastgir, 2017). On the other hand, financial performance has several limitations. For example, it has failed to represent long-term performance and the survival of the business (Harrison \& Wicks, 2013; Kaplan \& Norton, 1996), and it only emphasizes the maximising of shareholder's wealth (Barney, 2011). Another alternative measurement for company performance is Corporate Social Performance (CSP) (Aguilera-Caracuel et al., 2015; Kacperczyk, 2009; Neubaum \& Zahra, 2006).

CSP is closely related to the concept of Corporate Social Responsibility (CSR). According to (Aguilera-Caracuel et al., 2015), CSP might measure the implementation and success level in implementing CSR. Hence, CSP becomes a vital component of overall performance measurement (Brammer et al., 2006). However, research on the relationship between corporate diversification and CSP has been overlooked (Kang, 2013), particularly in product diversification (Patrisia \& Dastgir, 2017).

According to Reimann et al. (2015), every country has different local rules, regulations, and governmental control, which lead to different CSR requirements. Furthermore, CSP is a multidimensional construct (Kang, 2013; Walls et al., 2012). Therefore, different standards, agencies, and researchers use various CSP indicators. The previous studies on corporate diversification and CSP relationship mostly used Kinder, Lydenberg, Domini (KLD) indicators to measure CSP, such as Aguilera-Caracuel et al., (2015), Kang (2013), and Simerly (1997). KLD's indicators consist of environment, social, and governance indicators. Meanwhile, according to Bouten et al. (2011), Global Reporting Initiative (GRI) guidelines could be an adequate standard to measuring CSP. GRI had considered a credible organization that incorporates social activities disclosure (Gamerschlag et al., 2011). This standard-design by various experts based on stakeholders' input (Bouten et al., 2011). This standard also accepted globally (Bouten et al., 2011; Farneti \& Guthrie, 2009; Gamerschlag et al., 2011). Furthermore, most of the prior studies have been conducted in the developed market settings, such as the US and UK (Brammer et al., 2006; Kang, 2013; Simerly, 1997); nevertheless, it remains neglected in emerging economies (Patrisia \& Dastgir, 2017). Hence, this study asserts the study setting in an emerging market that might be different from the developed market setting.

CSP is a company performance measurement by using multiple stakeholder' perspectives (Kacperczyk, 2009; Zhang, 2012). Brammer et al. (2006) assert that CSP is a primary component of business performance. CSP becomes delighted since a company has got an intense pressure from stakeholders to show their commitment and contribution to society in social and environmental issues. Hence, we may argue that CSP is a performance measurement that reflects the company's response to stakeholder demands and social issues. 
Furthermore, some prior studies argue that CSP will influence by some factors, such as corporate diversification (Brammer et al., 2006; Kang, 2013). According to (Su \& Tsang, 2015), diversification refers to a company, which operates in more than one industry or product market. Moreover, Park and Jang (2012) argue that diversification implies a company is moving into several markets (sectors, industries, or segments), in which it was not previously engaged. Hence, a diversified company may have several different businesses or operate in multi businesses in terms of industry (product diversification), market, or resources.

According to several prior studies, industry, or product diversification might classify into related diversification and unrelated diversification (Castañer \& Kavadis, 2013; Chen \& Yu, 2012; Hashai, 2015). Related diversification refers to a diversification strategy that is associated with an expanding of business on a similar product or the same product line (Chen \& Yu, 2012). On the other hand, according to Castañer and Kavadis (2013), unrelated diversification refers to a diversification strategy that extends the company's operation into a different business that has different input-output configurations or has limited common resources. Hence, we argue that a company, which adopts the related diversification strategy, has some related products and services, or participates in the same industry. On the other hand, a company that adopts unrelated diversification has different products and services or participates in a different industry or market.

Furthermore, Kang (2013) asserts that diversification has a relationship with CSP for several reasons. First, it relies on the range of stakeholder demands and social issues faced by the company. Kang (2013) also argues that the stakeholders' quantity and diversity that are pertinent to a company have a close relationship with the operation of the company. Hence, it means that increasing the company's range of business operations, and it will increase the quantity and diversity of stakeholders and further could affect the range of stakeholder demands and social issues. Second, corporate diversification has an impact on the increase in the manager's risk aversion. According to Kang (2013), a diversification strategy influences the manager in choosing a prudent strategic decision that accommodates the stakeholders' demands and involves risk management. Third, diversification strategy may influence the reducing of the managerial employment risk trough minimizing the company bankruptcy risk and management entrenchment (Alesón \& Escuer, 2002). Finally, a diversified company shares the cost and benefit of the CSP-related investments across its subsidiaries (McWilliams $\&$ Siegel, 2001). Consequently, a diversified company has stronger economic encouragement to invest in social issues.

Previous researchers have asserted that the related and unrelated diversification have a link with the organizational performance (Kang, 2013; Miller, 2006; Park \& Jang, 2013; Purkayastha, 2013; Su \& Tsang, 2015) In term of related diversification, (Su \& Tsang, 2015) reveal that related diversification has no relationship with financial performance, whilst Miller (2006) notes that related diversification has a positive and significant relationship with company performance. In contrast, Gary (2005), Oh et al. (2015) found that a stronger related diversification strategy might lead to more mediocre performance. Moreover, according to Zahavi and Lavie (2013), the relationship between intra-industry 
diversification has a U-shaped effect on performance. In terms of unrelated diversification, Kim (1989) found that an unrelated diversification strategy might be positively associated with organizational performance when companies are well diversified globally. However, Purkayastha (2013) and Su \& Tsang (2015) note that unrelated diversification has a negative and significant relationship with financial performance, unless in a specific industry or different stakeholder. Although all of these studies did not employ CSP as the organizational performance measurement, it may argue that related and unrelated diversification has an impact on CSP, because one of the organizational performance dimensions is the CSP. However, prior studies on the link between related and unrelated diversification and CSP are minimal.

Also, Kang (2013), Patrisia \& Dastgir (2017) note the negative relationship between the related diversification-CSP relationship. Kang (2013) accepted that the relationship between the level of diversification and CSP does not necessarily have to be positive. If an unrelated diversified company cannot maintain a good relationship under pressure from increasing stakeholder demands and social issues, an increasing level of diversification might affect CSP negatively (Kang, 2013). The argument of Su \& Tsang (2015) also implies that related diversification leads to lower CSP. Kang (2013); Su \& Tsang (2015) believed that related diversified companies face a less narrow range of stakeholders, given the similarity of stakeholder demands and social issues. Narrow range stakeholder demand may not encourage a company to extend its social responsibility to other areas. However, the similarity in stakeholder demands and social issues enables companies to identify their stakeholders accurately and manage them effectively (Post et al., 2002; Su \& Tsang, 2015). Therefore, related diversified companies may have less difficulty in maintaining the relationship with their stakeholders, particularly secondary stakeholders, avoiding a waste of resources ( $\mathrm{Su} \&$ Tsang, 2015). On the other hand, the company which adopts unrelated diversification enter several industries and serve broader stakeholder demand and social issues. Therefore, unrelated diversification may have a higher response to CSP.

Some previous researchers such as Aguilera-Caracuel et al., (2015), Attig et al., (2016), Brammer et al., (2006), Kang (2013), Ma et al., (2016) have argued that international diversification has a positive relationship with CSP. In contrast, according to Strike et al. (2006), international diversification can be simultaneously socially responsible and irresponsible. However, Cho et al. (2015) found that the diversified international firm appears to have less CSR activities.

However, there were several reasons for the positive relationship between international diversification and CSP, as follows. First, international diversification increases the number and variety of stakeholder pressures derived from the different legal, regulatory, economic, cultural, and social circumstances in each country (Aguilera-Caracuel et al., 2015; Brammer et al., 2006; Kang, 2013). Secondly, diversified international firms have a more significant opportunity for organizational learning, as they receive new and valuable ideas from the more diverse context (Aguilera-Caracuel et al., 2015; Ma et al., 2016). Thirdly, international diversification increases managerial incentives to respond to stakeholders' 
demands and social issues (Aguilera-Caracuel et al., 2015; Kang, 2013). Fourthly, international diversification provides economic incentives for a company to respond to its stakeholders' demand and social issues (Aguilera-Caracuel et al., 2015; Kang, 2013; McWilliams \& Siegel, 2001).

According to the above literature review, this study has addressed some research gaps as follows: First, this study has investigated the link between corporate diversification (i.e., related, unrelated, and international diversification) and CSP that has been overlooked previously (Kang, 2013). Second, this study has adopted GRI indicators as the measurement of CSP. Previous research used KLD as the measurement of CSP. However, some studies have asserted that GRI is considered as a reliable measurement of corporate social activities disclosure (Gamerschlag et al., 2011). Hence, this study has introduced another alternative in measuring CSP. Third, most of the previous studies have conducted in developed countries, which are different from the emerging country study setting. Accordingly, this study has addressed this gap and gives another perspective from an emerging market perspective.

Therefore, this study has contributed to both theoretical development and managerial implication. First, for the theoretical development, this study has highlighted the link between corporate diversification (related, unrelated, and international diversification) on CSP that remains neglected in the previous studies. Moreover, this study has introduced another measurement of CSP by using GRI indicators that have limited previously. This study has also addressed the link between corporate diversification and CSP in the emerging country that might be different from the developed country study setting. Second, this study provides some input for the manager in addressing corporate diversification to increase the CSP.

\section{Methods}

The population of this study is Indonesian public companies that list on the Indonesia Stock Exchange (IDX). Furthermore, this study employs the purposive sampling method. From 459 companies, there are only 230 companies fulfilling all of the criteria. The data have collected from the company's annual report 2012 and Indonesia Capital Market Directory (ICMD) 2013. This study applies content analysis to measure CSP. The checklist of disclosure items for CSP indicators adapted from the Global Reporting Initiative (GRI). The related and unrelated diversification has measured by using the entropy measure relies on established product classification, such as international standard industrial classification of all economic activities (ISIC). Indonesia employs ISIC Rev 4 to develop its standard which called Klasifikasi Baku Lapangan Usaha Indonesia (KBLI) (BPS, 2009). Therefore, related diversification is reflected in the same two-digit ISIC code, although they have a different industry segment under four-digit ISIC codes. Unrelated diversification is the corporate strategy, which operates the business in a different business or industry group based on two-digit ISIC codes. International diversification measured by using the uni-dimensional measure, the ratio of foreign sales to total sales (Kang, 2013; 
Majocchi \& Strange, 2012). The formulas for related diversification and unrelated are as follows:

Equation 1 Related Diversification in several segments

$$
\mathrm{DR}_{\mathrm{j}}=\sum_{\mathrm{i} \varepsilon j} \mathrm{P}_{\mathrm{i}}^{\mathrm{j}} \ln \frac{1}{\mathrm{P}_{\mathrm{i}}^{\mathrm{j}}}
$$

Equation 2 Total Related Diversification

$$
\mathrm{DR}=\sum_{\mathrm{j}=1}^{\mathrm{m}} \mathrm{DR}_{\mathrm{j}} \times \mathrm{p}_{\mathrm{j}}
$$

Equation 3 Total Unrelated Diversification

$$
\mathrm{DU}=\sum_{\mathrm{j}=1}^{\mathrm{m}} \mathrm{P}^{\mathrm{j}} \ln \frac{1}{\mathrm{p}_{\mathrm{i}}}
$$

Where: $\mathrm{DR}_{\mathrm{j}}$ is the related diversification in several segments within an industry group; $\mathrm{P}_{\mathrm{i}}^{\mathrm{j}}$ is the share of the segment $i$ of group $j$ in the total sales of the group; DR is the weighted average of total related diversification within the entire group share; $p_{j}$ is the share of $j$ th group sales in the total sales of the company; DU is the weighted average of unrelated diversification in all entire group shares.

This study used some control variables, including company size (natural log of number of total employee), profitability (Return on Asset; percentage of earnings before interest and taxes to total assets), liquidity (current ratio; current asset to short term liabilities), financial leverage (Debt asset ratio; Total debt to total asset), Intangible assets (Market to book ratio; Market price to book value), company's age (number of year company established), type of industry (CSP industry based on two-digit ISIC), ownership concentration (public ownership: percentage of public ownership), and Independent commissioner (number of independent commissioners in companies). This study used multiple regression analysis, specifically multiple regression with one-year lag dependent variables, as the primary form of data analysis (Hair et al., 2010). This study used SPSS 24 as the software package for the data analysis. Also, this study has formulated the model equation as follows:

$$
\begin{aligned}
\mathrm{CSP}= & \alpha_{0+} \beta_{1} \mathrm{DR}+\beta_{2} \mathrm{DU}+\beta_{3} \mathrm{DI}+\beta_{4} \text { Size }+\beta_{5} \text { Profitability }+\beta_{6} \text { Liquidity } \\
& +\beta_{7} \text { Leverage }+\beta_{8} \text { Intangible Asset }+\beta_{9} \text { Age }+\beta_{10} \text { Type of Industry } \\
& +\beta_{11} \text { OwC }+\beta_{12} \mathrm{I}+\varepsilon
\end{aligned}
$$

\section{Result and Discussion}

Table 1 shows the descriptive statistic of 203 listed companies in Indonesia. This descriptive contains the mean, maximum, minimum, and standard deviation value. For instance, the minimum score of CSP is $3.75 \%$, and the maximum score is $53.75 \%$. Moreover, based on the mean value of three diversification strategies, the mean value of international diversification is higher than the related diversification and unrelated diversification. Also, the level of the unrelated diversification is higher than the level of the related diversification.

Furthermore, Pearson's correlation between the variables shows in Table 2. Some of the correlation values between variables are significant, but no correlation value is reached 0.90 . Accordingly, there is no sign of the multicollinearity problem. 
Based on the analysis results in the appendix, model 2 and model 5 show that the related diversification has a negative and significant relationship with CSP. Moreover, Model 3 and Model 5 have examined the link between the unrelated diversification and CSP. The result shows that the unrelated diversification has a positive and significant impact on CSP. Model 4 and model5 show that the international diversification has a significant and positive link with CSP.

Table 1 Descriptive Statistic

\begin{tabular}{lccccc}
\hline \multicolumn{1}{c}{ Variables } & N & Minimum & Maximum & Mean & Std. Deviation \\
\hline CSP & 203 & 3.75 & 53.75 & 20.222 & 9.322 \\
Related Diversification & 203 & 0.00 & 0.81 & 0.085 & 0.193 \\
Unrelated Diversification & 203 & 0.00 & 1.07 & 0.253 & 0.316 \\
International Diversification & 203 & 0.00 & 100.00 & 17.943 & 27.622 \\
Size & 203 & 2.48 & 11.22 & 6.950 & 1.695 \\
Profitability & 203 & -25.38 & 45.55 & 6.991 & 10.348 \\
Liquidity & 203 & 0.23 & 7.73 & 2.003 & 1.434 \\
Financial Leverage & 203 & 0.04 & 1.32 & 0.504 & 0.217 \\
Intangible Asset & 203 & -3.16 & 9.65 & 2.082 & 1.953 \\
Age & 203 & 1.10 & 4.71 & 3.234 & 0.637 \\
CSP Industry & 203 & 12.50 & 40.00 & 20.874 & 5.701 \\
Ownership concentration & 203 & 1.00 & 83.46 & 26.067 & 17.130 \\
Independent Commissioner & 203 & 1.00 & 4.00 & 1.645 & 0.772 \\
\hline
\end{tabular}

This study found that related diversification has a negative relationship with CSP. This finding is in line with some prior studies (Gary, 2005; Kang, 2013; Oh et al., 2015; Patrisia \& Dastgir, 2017). For example, Gary (2005); Oh et al. (2015) have argued that related diversification is an antecedent of the organizational performance negatively. It is because the management's policies are absence in maintaining the organizational slack Even though Gary and Oh et al. did not address CSP as the organizational performance dimension; we conclude that the related diversification is negatively related to CSP. Moreover, Kang (2013); Patrisia \& Dastgir (2017) also assert that related diversification has a negative relationship with CSP. Hence, the negative impact may occur because the diversified company neglects the increasing of stakeholder demands and social issues.

Furthermore, we found that the link between unrelated diversification and CSP is positive and significant. This finding supports some previous studies (Kang, 2013; Park \& Jang, 2013; Su \& Tsang, 2015). For example, Su and Tsang (2015) argue that the unrelated diversification is positively and significantly related to organizational performance, since unrelated diversified firms have various stakeholders. This finding is also congruent with Purkayastha (2013) who assert that the unrelated diversification increases the organizational performance in a specific industry such as transportation. Although both Purkayastha and 
Su et al. have not directly investigated CSP as the organizational performance, we argue that CSP as a dimension of organizational performance is a consequence of the unrelated diversification. Accordingly, when a company has diversified into unrelated businesses, it will have an impact on a better CSP.

Table 2. Pearson's and Spearman's Correlation Matrices of the Variables

\begin{tabular}{|c|c|c|c|c|c|c|c|c|c|c|c|c|c|}
\hline No & Variables & 1 & 2 & 3 & 4 & 5 & 6 & 7 & 8 & 9 & 10 & 11 & 12 \\
\hline 1 & CSP & & & & & & & & & & & & \\
\hline 2 & $\begin{array}{l}\text { Related } \\
\text { Diversification }\end{array}$ & -.031 & & & & & & & & & & & \\
\hline 3 & $\begin{array}{l}\text { Unrelated } \\
\text { Diversification }\end{array}$ & $.166^{* *}$ & -.051 & & & & & & & & & & \\
\hline 4 & $\begin{array}{l}\text { International } \\
\text { Diversification }\end{array}$ & $.208^{* *}$ & .040 & -.055 & & & & & & & & & \\
\hline 5 & Size & $.389 * *$ & $.240^{* *}$ & $.241^{* *}$ & .104 & & & & & & & & \\
\hline 6 & Profitability & .107 & .033 & $.145^{*}$ & -.060 & $.127^{*}$ & & & & & & & \\
\hline 7 & Liquidity & $-.167^{* *}$ & -.010 & -.044 & -.055 & $-.124^{*}$ & $.325^{* *}$ & & & & & & \\
\hline 8 & Financial Leverage & -.022 & .041 & -.018 & .111 & .076 & $-.477^{* *}$ & $-.643^{* *}$ & & & & & \\
\hline 9 & Intangible Asset & .020 & -.103 & -.021 & $-.146^{*}$ & .010 & $.327^{* *}$ & $.125^{*}$ & $-.131^{*}$ & & & & \\
\hline 10 & Age & .078 & .041 & $.126^{*}$ & .046 & $.164^{* *}$ & .022 & .106 & .028 & $-.117^{*}$ & & & \\
\hline 11 & CSP Industry & $.333^{* *}$ & .077 & -.108 & $.138^{*}$ & .094 & .022 & -.026 & $-.120^{*}$ & .014 & .019 & & \\
\hline 12 & $\begin{array}{l}\text { Ownership } \\
\text { Concentration }\end{array}$ & $.251^{* *}$ & $.160 *$ & .049 & -.043 & .098 & -.027 & -.015 & -.013 & $-.143^{*}$ & .016 & .078 & \\
\hline 13 & $\begin{array}{l}\text { Independent } \\
\text { Commissioner }\end{array}$ & $.322^{* *}$ & $.118^{*}$ & -.070 & $.125^{*}$ & $.413^{* * *}$ & .085 & .009 & .039 & $.153^{*}$ & .041 & $.136^{*}$ & .064 \\
\hline
\end{tabular}

This study has also found that international diversification has a positive and significant impact on CSP. This finding is similar to some prior studies such asAguilera-Caracuel et al. (2015), Brammer et al. (2006), Kang (2013). For example, Kang (2013) emphasizes that international diversification is an antecedent of organizational performance. Moreover, Aguilera-Caracuel et al. (2015) also argue that the company's policy will influence organizational performance in doing diversification internationally. Therefore, to increase the CSP of a company, the managers should give more concern on how their companies have diversified internationally.

\section{Conclusion}

In conclusion, this study has contributed to both theoretical development and managerial implications. This study has revealed three theoretical contributions. Firstly, it gives a new understanding of how corporate diversification (related, unrelated, and international diversification) is related to the CSP. To the best of our knowledge, only one study thas has accurately addressed the relationship between corporate diversification and CSP. Secondly, this study preferred to employ GRI as the CSP indicator instead of KLD that used in the previous study. Hence, this study has expanded the measurement of CSP by using the GRI Indicator. Thirdly, this study conducted in an emerging country that has different 
characteristics with developed countries. On the other hand, most of the prior studies have conducted in developed countries. Hence, this study gives another perspective on the link between diversification and CSP.

Furthermore, this study has highlighted practical implications for managers and policymakers. For instance, this study provides a better understanding of the managers in managing CSP in the company. This study also gives input for the government in creating a better regulation on the company's participation in the social responsibility issues, which will increase the CSP. However, this study is not free from some limitations. First, this study is only one country's study; hence, it has a generalizability issue. Second, this study is a crosssectional study. Thus, it only captures the phenomena at one time, and indeed, it has a lack of generalizability. Therefore, for future research, we suggest conducting a study in some countries such as Southeast Asia countries, and it can expand into a longitudinal study that has a more generalizable result. Furthermore, future studies may include other antecedents of CSP, such as good corporate governance (GCG).

\section{References}

Aguilera-Caracuel, J., Guerrero-Villegas, J., Vidal-Salazar, M. D., \& Delgado-Márquez, B. L. (2015). International Cultural Diversification and Corporate Social Performance in Multinational Enterprises: The Role of Slack Financial Resources. Management International Review, 55(3), 323-353. https://doi.org/10.1007/s11575-014-0225-4.

Alesón, M. R., \& Escuer, M. E. (2002). The Impact of Product Diversification Strategy on the Corporate Performance of Large Spanish Firms. Spanish Economic Review, 4(2), 119-137. https://doi.org/10.1007/s101080200042.

Attig, N., Boubakri, N., El Ghoul, S., \& Guedhami, O. (2016). Firm Internationalization and Corporate Social Responsibility. Journal of Business Ethics, 134(2), 171-197. https://doi.org/10.1007/s10551-014-2410-6.

Barney, J. B. (2011). Gaining and Sustaining Competitive Advantage. Boston: Pearson.

Bouten, L., Everaert, P., Van Liedekerke, L., De Moor, L., \& Christiaens, J. (2011). Corporate Social Responsibility Reporting: A Comprehensive Picture? Accounting Forum, 35(3), 187-204. https://doi.org/10.1016/j.accfor.2011.06.007.

BPS. (2009). Klasifikasi Baku Lapangan Usaha Indonesia. Jakarta: BPS.

Brammer, S. J., Pavelin, S., \& Porter, L. A. (2006). Corporate Social Performance and Geographical Diversification. Journal of Business Research, 59(9), 1025-1034. https:// doi.org/10.1016/j.jbusres.2006.04.001.

Castañer, X., \& Kavadis, N. (2013). Does Good Governance Prevent Bad Strategy? a Study of Corporate Governance, Financial Diversification, and Value Creation by French Corporations, 2000-2006. Strategic Management Journal, 34(7), 863-876.

Chen, C.-J., \& Yu, C.-M. J. (2012). Managerial Ownership, Diversification, and Firm Performance: Evidence from an Emerging Market. Journal of Management Studies, 21(3), 518-534. 
Cho, E., Chun, S., \& Choi, D. (2015). International Diversification, Corporate Social Responsibility, and Corporate Governance: Evidence From Korea. Journal of Applied Business Research, 31(2), 743.

Farneti, F., \& Guthrie, J. (2009). Sustainability Reporting by Australian Public Sector Organisations: Why They Report. Accounting Forum, 33(2), 89-98. https://doi. org/10.1016/j.accfor.2009.04.002.

Gamerschlag, R., Möller, K., \& Verbeeten, F. (2011). Determinants of voluntary CSR disclosure: empirical evidence from Germany. Review of Managerial Science, 5(2), 233262. https://doi.org/10.1007/s11846-010-0052-3.

Gary, M. S. (2005). Implementation Strategy and Performance Outcomes in Related Diversification. Strategic Management Journal, 26(7), 643-664. https://doi.org/ 10.1002/ smj. 468

Hair, J. F., Black, W. C., Babin, B. J., \& Anderson, R. E. (2010). Multivariate Data Analysis. New Jersey: Prentice Hall.

Harrison, J. S., \& Wicks, A. C. (2013). Stakeholder theory, value, and firm performance. Business ethics quarterly, 23(1), 97-124.

Hashai, N. (2015). Within-industry diversification and firm performance-an S-shaped hypothesis. Strategic Management Journal, 36(9), 1378-1400. https://doi.org/10.1002/ smj. 2290

Kacperczyk, A. (2009). With Greater Power Comes Greater Responsibility? Takeover Protection and Corporate Attention to Stakeholders. Strategic Management Journal, 30(3), 261-285.

Kang, J. (2013). The Relationship between Corporate Diversification and Corporate Social Performance. Strategic Management Journal, 34(1), 94-109. https://doi.org /10.1002/ smj.2005

Kaplan, R. S., \& Norton, D. P. (1996). The Balanced Scorecard: Translating Strategy into Action. Boston: Harvard Business School Press.

Kim, W. C. (1989). NOTES: Developing a Global Diversification Measure. Management Science, 35(3), 376.

Ma, H., Zeng, S., Shen, G. Q., Lin, H., \& Chen, H. (2016). International Diversification and Corporate Social Responsibility. Management Decision, 54(3), 750-774. https:// doi.org/10.1108/MD-07-2015-0322

Majocchi, A., \& Strange, R. (2012). International Diversification: The Impact of Ownership Structure, the Market for Corporate Control and Board Independence. Management International Review, 52(6), 879.

McWilliams, A., \& Siegel, D. (2001). Corporate Social Responsibility: A Theory of the Firm Perspective. The Academy of Management Review, 26(1), 117-127.

Miller, D. J. (2006). Technological Diversity, Related Diversification, and Firm Performance. Strategic Management Journal, 27(7), 601-619. https://doi.org/ 10.1002/smj.533

Neubaum, D. O., \& Zahra, S. A. (2006). Institutional Ownership and Corporate Social Performance: The Moderating Effects of Investment Horizon, Activism, and Coordination. Journal of Management, 32(1), 108-131. 
Oh, C. H., Sohl, T., \& Rugman, A. M. (2015). Regional and Product Diversification and The Performance of Retail Multinationals. Journal of International Management, 21(3), 220-234. https://doi.org/10.1016/j.intman.2015.04.002.

Park, K., \& Jang, S. (2013). Capital Structure, Free Cash Flow, Diversification and Firm Performance: a Holistic Analysis. International Journal of Hospitality Management, 33(1), 51-63. https://doi.org/10.1016/j.ijhm.2013.01.007.

Park, K., \& Jang, S. S. (2012). Effect of Diversification on Firm Performance: Application of the Entropy Measure. International Journal of Hospitality Management, 31(1), 218228. https://doi.org/10.1016/j.ijhm.2011.03.011.

Patrisia, D., \& Dastgir, S. (2017). Diversification and corporate social performance in manufacturing companies. Eurasian Business Review, 7(1), 121-139. https:/doi.org/ 10.1007/s40821-016-0052-6.

Post, J. E., Preston, L. E., \& Sachs, S. (2002). Managing the Extended Enterprise: The New Stakeholder View. California Management Review, 45(1), 6-28. https://doi. org/10.2307/41166151.

Purkayastha, S. (2013). Diversification Strategy and Firm Performance: Evidence from Indian Manufacturing Firms. Global Business Review, 14(1), 1-23.

Reimann, F., Rauer, J., \& Kaufmann, L. (2015). MNE Subsidiaries' Strategic Commitment to CSR in Emerging Economies: The Role of Administrative Distance, Subsidiary Size, and Experience in the Host Country. Journal of Business Ethics, 132(4), 845-857. https://doi.org/10.1007/s10551-014-2334-1.

Simerly, R. L. (1997). An Empirical Examination of the Relationship Between Corporate Social Performance and Firms' Diversification. Psychological Reports, 80(3), 1347-1356. https://doi.org/10.2466/pr0.1997.80.3c.1347.

Strike, V. M., Gao, J., \& Bansal, P. (2006). Being Good While Being Bad: Social Responsibility and the International Diversification of US Firms. Journal of International Business Studies, 37(6), 850-862. https://doi.org/10.1057/ palgrave.jibs.8400226.

Su, W., \& Tsang, E. W. K. (2015). Product Diversification and Financial Performance: The Moderating Role of Secondary Stakeholders. Academy of Management Journal, 58(4), 1128-1148. https://doi.org/10.5465/amj.2013.0454.

Walls, J. L., Berrone, P., \& Phan, P. H. (2012). Corporate Governance and Environmental Performance: Is There Really a Link? Strategic Management Journal, 33(8), 885-913.

Wan, W. P., Hoskisson, R. E., Short, J. C., \& Yiu, D. W. (2011). Resource-based Theory and Corporate Diversification: Accomplishments and Opportunities. Journal of Management, 37(5), 1335-1368. https://doi.org/10.1177/0149206310391804.

Zahavi, T., \& Lavie, D. (2013). Intra-industry Diversification and Firm Performance. Strategic Management Journal, 34(8), 978-998. https://doi.org/10.1002/smj.2057.

Zhang, L. (2012). Board Demographic Diversity, Independence, and Corporate Social Performance. Corporate Governance, 12(5), 686-700. 
Dina Patrisia. Corporate Diversification and Corporate Social Performance

\section{Appendix}

\section{Coefficient and Significance for Models 1 to 5}

\begin{tabular}{|c|c|c|c|c|c|c|c|c|c|c|c|}
\hline & \multicolumn{2}{|c|}{ Model 1} & \multicolumn{2}{|c|}{ Model 2} & \multicolumn{2}{|c|}{ Model 3} & \multicolumn{2}{|c|}{ Model 4} & \multicolumn{3}{|c|}{ Model 5} \\
\hline & B & $P$ & B & $\mathrm{P}$ & B & $\mathrm{P}$ & B & $\mathrm{P}$ & B & Beta & $\mathrm{P}$ \\
\hline Constant & $\begin{array}{c}0.019 \\
(4.713)\end{array}$ & 0.997 & $\begin{array}{l}-1.654 \\
(4.662)\end{array}$ & 0.723 & $\begin{array}{l}-0.098 \\
(4,677)\end{array}$ & 0.983 & $\begin{array}{c}0.663 \\
(4.653)\end{array}$ & 0.887 & $\begin{array}{l}-0.966 \\
(4.573)\end{array}$ & & 0.000 \\
\hline Size & $\begin{array}{c}1.292^{* * *} \\
(0.369)\end{array}$ & 0.001 & $\begin{array}{c}21.494^{* * *} \\
(0.369)\end{array}$ & 0.000 & $\begin{array}{c}1.098^{* * *} \\
(0.379)\end{array}$ & 0.004 & $\begin{array}{l}1.252^{* * *} \\
(0.365)\end{array}$ & 0.001 & $\begin{array}{c}1.262 \\
(0.377)\end{array}$ & $0.230^{* * *}$ & 0.001 \\
\hline Profitability & $\begin{array}{c}0.063 \\
(0.064)\end{array}$ & 0.325 & $\begin{array}{c}0.074 \\
(0.063)\end{array}$ & 0.243 & $\begin{array}{c}0.048 \\
(0.064)\end{array}$ & 0.459 & $\begin{array}{c}0.060 \\
(0.063)\end{array}$ & 0.349 & $\begin{array}{c}0.055 \\
(0.062)\end{array}$ & 0.061 & 0.382 \\
\hline Liquidity & $\begin{array}{c}-1.639 * * * \\
(0.516)\end{array}$ & 0.002 & $\begin{array}{c}-.1549 * * * \\
(0.508)\end{array}$ & 0.003 & $\begin{array}{c}-1.565^{* * *} \\
(0.514)\end{array}$ & 0.003 & $\begin{array}{c}-1.700^{* * *} \\
(0.509)\end{array}$ & 0.001 & $\begin{array}{c}-1.551^{* * *} \\
(0.499)\end{array}$ & $-0.239^{* * *}$ & 0.002 \\
\hline $\begin{array}{l}\text { Financial } \\
\text { leverage }\end{array}$ & $\begin{array}{l}-6.186^{*} \\
(3.664)\end{array}$ & 0.093 & $\begin{array}{l}-5.422 \\
(3.606)\end{array}$ & 0.134 & $\begin{array}{l}-5.947 \\
(3.638)\end{array}$ & 0.104 & $\begin{array}{l}-7.173^{*} \\
(3.633)\end{array}$ & 0.050 & $\begin{array}{l}-6.280 * \\
(3.553)\end{array}$ & -0.146 & 0.079 \\
\hline $\begin{array}{l}\text { Intangible } \\
\text { asset }\end{array}$ & $\begin{array}{c}0.054 \\
(0.306)\end{array}$ & 0.860 & $\begin{array}{l}-0.040 \\
(0.302)\end{array}$ & 0.894 & $\begin{array}{c}0.065 \\
(0.303)\end{array}$ & 0.831 & $\begin{array}{c}0.183 \\
(0.306)\end{array}$ & 0.551 & $\begin{array}{c}0.109 \\
(0.300)\end{array}$ & 0.023 & 0.716 \\
\hline Age & $\begin{array}{c}0.809 \\
(0.892)\end{array}$ & 0.366 & $\begin{array}{c}0.750 \\
(0.876)\end{array}$ & 0.393 & $\begin{array}{c}0.637 \\
(0.890)\end{array}$ & 0.475 & $\begin{array}{c}0.808 \\
(0.880)\end{array}$ & 0.359 & $\begin{array}{c}0.598 \\
(0.862)\end{array}$ & 0.041 & 0.489 \\
\hline CSP Industry & $\begin{array}{c}0.400^{* * *} \\
(0.099)\end{array}$ & 0.000 & $\begin{array}{c}0.417^{* * *} \\
(0.097)\end{array}$ & 0.000 & $\begin{array}{c}0.426^{* * *} \\
(0.099)\end{array}$ & 0.000 & $\begin{array}{c}0.0363^{* * *} \\
(0.098)\end{array}$ & 0.000 & $\begin{array}{c}0.401^{* * *} \\
(0.097)\end{array}$ & $0.246^{* * *}$ & 0.000 \\
\hline $\begin{array}{l}\text { Ownership } \\
\text { concentration }\end{array}$ & $\begin{array}{c}0.105^{* * *} \\
(0.032)\end{array}$ & 0.001 & $\begin{array}{c}0.117^{* * *} \\
(0.032)\end{array}$ & 0.000 & $\begin{array}{l}0.103^{* * *} \\
(0.032)\end{array}$ & 0.002 & $\begin{array}{c}0.113^{* * *} \\
(0.032)\end{array}$ & 0.001 & $\begin{array}{c}0.121^{* * *} \\
(0.032)\end{array}$ & $0.223 * * *$ & 0.000 \\
\hline $\begin{array}{l}\text { Independent } \\
\text { commisioner }\end{array}$ & $\begin{array}{c}2.126^{* * *} \\
(0.615)\end{array}$ & 0.008 & $\begin{array}{c}2.173^{* * *} \\
(0.782)\end{array}$ & 0.006 & $\begin{array}{c}2.401^{* * *} \\
(0.802)\end{array}$ & 0.003 & $\begin{array}{l}1.924^{* *} \\
(0.020)\end{array}$ & 0.016 & $\begin{array}{c}2.210^{* * *} \\
(0.780)\end{array}$ & $0.184^{* * *}$ & 0.005 \\
\hline $\begin{array}{l}\text { Related } \\
\text { diversification }\end{array}$ & & & $\begin{array}{c}-8.381 * * * \\
(2.906)\end{array}$ & 0.004 & & & & & $\begin{array}{c}-7.706^{* * *} \\
(2.866)\end{array}$ & $-0.160^{* * *}$ & 0.008 \\
\hline $\begin{array}{l}\text { Unrelated } \\
\text { diversification }\end{array}$ & & & & & $\begin{array}{c}3.656^{* * *} \\
(0.581)\end{array}$ & 0.048 & & & $\begin{array}{l}3.308^{*} \\
(1.796)\end{array}$ & $0.113^{*}$ & 0.067 \\
\hline $\begin{array}{l}\text { International } \\
\text { diversification }\end{array}$ & & & & & & & $\begin{array}{c}0.052^{* * *} \\
(0.560)\end{array}$ & 0.011 & $\begin{array}{c}0.053^{* * *} \\
(0.020)\end{array}$ & $0.158^{* * *}$ & 0.008 \\
\hline
\end{tabular}

Significance level: ${ }^{* * *},{ }^{* *}$, and ${ }^{*}$ is significant at the $1 \%, 5 \%$ and $10 \%$ level, respectively. 